\title{
Neurohormone Secretion Persists after Post-Afterdischarge Membrane Depolarization and Cytosolic Calcium Elevation in Peptidergic Neurons in Intact Nervous Tissue
}

\author{
Stephan Michel and Nancy L. Wayne \\ Department of Physiology, David Geffin School of Medicine at University of California at Los Angeles, Los Angeles, \\ California 90095
}

The purpose of this work was to test the hypothesis that an electrical afterdischarge (AD) causes prolonged elevation in cytosolic calcium levels that is associated with prolonged secretion of egg-laying hormone (ELH) from peptidergic neurons in intact nervous tissue of Aplysia. Using a combination of radioimmunoassay measurement of ELH secretion, electrophysiological measurement of membrane potential, and optical imaging of the concentration of intracellular free calcium ions $\left(\left[\mathrm{Ca}^{2+}\right]_{\mathrm{i}}\right)$, we verified that there was persistent secretion of ELH after the end of the $A D$; this was accompanied by prolonged post-AD membrane depolarization and prolonged post-AD elevation in $\left[\mathrm{Ca}^{2+}\right]_{i}$. Extracellular treatment with the calcium chelator EGTA had no effect on the pattern or magnitude of ELH secretion or on the post-AD membrane potential $\left(V_{m}\right)$ and post-AD $\mathrm{Ca}^{2+}$ signal, ruling out a role for extracellular calcium in the post-AD elevation of $\left[\mathrm{Ca}^{2+}\right]_{\mathrm{i}}$. Both $V_{\mathrm{m}}$ and $\left[\mathrm{Ca}^{2+}\right]_{\mathrm{i}}$ returned to baseline well before ELH secretion, such that neither prolonged membrane depolarization nor prolonged $\mathrm{Ca}^{2+}$ signaling can fully account for the extent of the persistent secretion of ELH. These findings suggest a unique relationship between membrane excitability, $\mathrm{Ca}^{2+}$ signaling, and prolonged neuropeptide secretion.

Key words: action potential; Aplysia; bag cell neurons; calcium imaging; calcium signaling; egg-laying hormone; exocytosis; membrane potential; neuroendocrine; neurosecretion
Dependence of exocytosis on $\mathrm{Ca}^{2+}$ influx from extracellular fluid is well documented in a variety of neurons, including dorsal root ganglion cells (Dunlap et al., 1989), motor neurons (Katz and Miledi, 1967), and hypothalamic magnocellular neurons (Mason et al., 1992). These studies and other work have provided a large body of evidence supporting a widely accepted model for the control of neurosecretion that involves membrane depolarization causing opening of voltage-sensitive calcium channels (VSCCs), allowing $\mathrm{Ca}^{2+}$ influx, leading to a rise in $\left[\mathrm{Ca}^{2+}\right]_{\mathrm{i}}$ that is critical for secretion. If $\mathrm{Ca}^{2+}$ influx is prevented, then neurosecretion comes to a rapid halt. However, there are several examples of excitable cells and neurons in which secretion is not completely dependent on $\mathrm{Ca}^{2+}$ influx. Exocytosis from rat gonadotropes (Tse et al., 1993), GABA secretion from catfish retinal neurons (Schwartz, 1987), and hormone secretion from Aplysia bag cell neurons (BCNs) (Wayne et al., 1998a) have been shown to persist in the absence of $\mathrm{Ca}^{2+}$ influx. In both gonadotropes and $\mathrm{BCNs}$, $\mathrm{Ca}^{2+}$ release from intracellular stores was sufficient to stimulate secretion (Tse et al., 1997; Wayne et al., 1998a). The present work explored the relationship between membrane excitability, $\mathrm{Ca}^{2+}$ signaling, and neuropeptide secretion using the BCNs of the marine mollusk Aplysia as a model system.

Unlike most neurosecretory cells from vertebrate CNS, the BCNs are a homogeneous population of neurons located in two discrete clusters in the Aplysia CNS, facilitating their identification

Received May 14, 2002; revised July 30, 2002; accepted Aug. 1, 2002

This work was supported by National Institutes of Health Grant NS 33548 (N.L.W.). We thank Sarah Buxton for technical assistance.

Correspondence should be addressed to Nancy L. Wayne, Department of Physiology, Room 53-231CHS, David Geffin School of Medicine at the University of California at Los Angeles, 10833 Le Conte Avenue, Los Angeles, CA 90095. E-mail: nwayne@mednet.ucla.edu.

Copyright (ㄷ 2002 Society for Neuroscience $\quad 0270-6474 / 02 / 229063-07 \$ 15.00 / 0$ in living tissue. In response to synaptic input, BCNs show a repetitive pattern of synchronous action-potential firing called an afterdischarge (AD) (Kupfermann and Kandel, 1970). This AD triggers exocytotic release of the peptide egg-laying hormone (ELH) (Chiu et al., 1979; Newcomb and Scheller, 1990; Wayne and Wong, 1994). ELH diffuses to target sites at the ovotestis, stimulating ovulation, and at the CNS, altering behaviors associated with egg laying (Rothman et al., 1983; Bernheim and Mayeri, 1995). Work using either intact nervous tissue maintained in vitro or freely behaving Aplysia showed that ELH secretion persisted for $\geq 40$ min after the end of the AD (Wayne, 1994; Wayne and Wong, 1994). Because the $\mathrm{BCN} \mathrm{Ca}^{2+}$ current is activated at high voltage ( $V_{\mathrm{m}}$ more positive than $-10 \mathrm{mV}$ ) (Fieber, 1995), as occurs only during action potential firing, it was hypothesized that extracellular $\mathrm{Ca}^{2+}$ would not play an important role in maintaining $\mathrm{ELH}$ secretion after the end of the AD. That turned out to be the case. Once the AD was initiated, preventing $\mathrm{Ca}^{2+}$ influx did not inhibit ELH secretion (Wayne and Frumovitz, 1995; Wayne et al., 1998a). Furthermore, in the absence of an $\mathrm{AD}$, release of $\mathrm{Ca}^{2+}$ from organelles while $\mathrm{Ca}^{2+}$ influx from extracellular fluid was blocked was sufficient to stimulate persistent secretion of ELH (Wayne et al., 1998a). The purpose of the present set of experiments was to determine whether $\mathrm{AD}$ produces a prolonged $\mathrm{Ca}^{2+}$ signal that persists in the absence of $\mathrm{Ca}^{2+}$ influx from extracellular fluid and that correlates with the duration of ELH secretion.

Parts of this work have been published previously in abstract form (Wayne and Michel, 2001).

\section{MATERIALS AND METHODS}

Animals and solutions. Aplysia californica, weighing 200-300 gm, were purchased from Alacrity Marine Biological Services (Redondo Beach, CA) and maintained in a recirculating seawater system. Water temperature was $20 \pm 1^{\circ} \mathrm{C}$; a $12 \mathrm{hr}$ light/dark cycle was used. Only animals that 
were reproductively mature and demonstrated the ability to lay eggs in response to injection with an ELH-like peptide from atrial gland extract were used in these experiments (Heller et al., 1980). Before dissection, animals were immobilized by injection of a volume of cold isotonic $\mathrm{MgCl}_{2}$ that was $\sim 30 \%$ of their body weight.

Bag cell preparations were maintained and treated with the following solutions. Unless otherwise noted, chemicals were purchased from Sigma (St. Louis, MO). The $\mathrm{pH}$ of all external solutions ranged from 7.65 to 7.80; the $\mathrm{pH}$ of solutions used in the intracellular recording and microinjection electrode was 7.4. Filtered artificial sea water (ASW) contained the following: $395 \mathrm{~mm} \mathrm{NaCl}, 10 \mathrm{~mm} \mathrm{KCl}, 10 \mathrm{~mm} \mathrm{CaCl}_{2}, 50 \mathrm{~mm} \mathrm{MgCl}_{2}$, $28 \mathrm{mM} \mathrm{Na}_{2} \mathrm{SO}_{4}, 30 \mathrm{mM} \mathrm{HEPES}$, and $5000 \mathrm{U} / 1$ penicillin-streptomycin. EGTA-ASW contained the following (in $\mathrm{mm}$ ): $419 \mathrm{NaCl}, 10 \mathrm{KCl}, 5$ $\mathrm{CaCl}_{2}, 50 \mathrm{MgCl}_{2}, 28 \mathrm{Na}_{2} \mathrm{SO}_{4}, 30 \mathrm{HEPES}$, and 10 EGTA. The microelectrode solution contained $0.5 \mathrm{M} \mathrm{KCl}$ and $10 \mathrm{mM} \mathrm{HEPES}$. Fura-PE3 (TEF Labs, Austin, TX) was dissolved in the $0.5 \mathrm{M} \mathrm{KCl}$ solution to a working concentration of $10 \mathrm{~mm}$, which minimized the volume needed for microinjection.

Electrophysiology recording and sample collection. The abdominal ganglion containing the bilateral BCN clusters and attached pleurovisceral connective nerves were dissected from the animal and placed in a flow-through recording chamber (P1; Warner Instruments, Hamden, CT) filled with $1 \mathrm{ml}$ of ASW containing 2\% Protenate (Baxter Healthcare, Glendale, CA) and a cocktail of peptidase inhibitors $(25 \mathrm{mg} / 100 \mathrm{ml}$ each of bacitracin, type II-0 ovomucoid/ovoinhibitor trypsin inhibitor from chicken egg white, and type III-0 ovomucoid trypsin inhibitor from chicken egg white). The neural preparation was glued to a glass coverslip at the bottom of the chamber using Instant Krazy glue (Elmer's Products, Columbus, $\mathrm{OH}$ ). Temperature in the recording chamber was maintained at $21-22^{\circ} \mathrm{C}$ throughout the experiments. After transfer to the recording chamber, holes were cut in the ganglion sheath above each BCN cluster to expose the cells for microelectrode impalement. The artery leading to the abdominal ganglion and BCN clusters was cannulated with a microbore Tygon tubing (Saint-Gomain Performance Plastics, Akron, OH) and fastened with suture. Solution was then perfused throughout the experiment at a rate of $10 \mu \mathrm{l} / \mathrm{min}$. This rate of delivery is estimated to perfuse the vascular space within the abdominal ganglion 10 times per minute (Mayeri et al., 1985) and washed out $100 \%$ of a perfused bolus of radiolabeled ELH within a 5 min sample period (Wayne and Frumovitz, 1995). At the end of each experiment, fast green dye was added to the perfusate, and its passage through abdominal ganglion and BCN clusters was monitored to determine whether the perfusion was successful. Perfusion through the artery ensured that ELH was maximally flushed out of the vascular space and into the surrounding medium and that solution was delivered rapidly to the intact bag cell clusters (Wayne and Wong, 1994). Solution surrounding the preparation was exchanged completely every $5 \mathrm{~min}$, starting during the pretreatment period and ending 90 min after onset of the AD. Therefore, each sample contained 5 min worth of secretory material. A low-flow perfusion pump (Lambda Pump model 700; Instech Laboratories, Plymouth Meeting, PA) was used to pump solution through the recording chamber and into the collection tubes at a steady rate, providing $95 \%$ recovery of a known amount of test protein by the second 5 min fraction. Samples were then stored at $-20^{\circ} \mathrm{C}$ until assay.

Afterdischarges were stimulated with a suction electrode placed on the pleurovisceral connective nerve $(40 \mathrm{~V}, 6 \mathrm{~Hz}, 40 \mathrm{msec} / \mathrm{pulse}, 5 \mathrm{sec}$ duration) (S88 Stimulator; Grass Instruments, Quincy, MA). For extracellular recording, BCN action potentials were monitored with a suction electrode placed on the ipsilateral bag cell cluster. A bioelectric amplifier with chart recorder (TA240; Gould Electronics, Valley View, OH) was used to amplify and record the action potentials. For intracellular recording, membrane potential $\left(V_{\mathrm{m}}\right)$ was monitored with a sharp microelectrode $\left(R_{\mathrm{el}}=20-30 \mathrm{M} \Omega\right)$ pulled from borosilicate glass $[1.5 \mathrm{~mm}$ diameter; World Precision Instruments (Sarasota, FL) and P87 from Sutter Instruments (Novato, CA)]. The signal was amplified using an intracellular amplifier (Intra 767; World Precision Instruments), monitored on a digital storage oscilloscope (VC-6025A; Hitachi Denshi, Woodbury, NY) and stored on a Macintosh Power personal computer (Apple Computer, Cupertino, CA) using MacLab data acquisition and analysis instrumentation and software (ADInstruments, Castle Hill, Australia). Electrical recording began $\geq 15 \mathrm{~min}$ before electrical stimulation. Microinjection of the calcium indicator dye fura-PE3 was aided by a micromanipulator (MP-285; Sutter Instruments) and achieved by a valvecontrolled pressure application $(\sim 150 \mathrm{kPa})$ through the same microelectrode as used for monitoring $V_{\mathrm{m}}$.
Optical imaging of cytosolic $\mathrm{Ca}^{2+}$. The recording chamber was placed under an upright microscope (BX50W; Olympus Optical, Melville, NY) equipped with a $40 \times$ water-immersion objective ( 0.8 numerical aperture; Olympus Optical). Infrared differential-contrast optics and an infrared camera (OL-1500; Olympus Optical) allowed the visual selection of BCNs and control of microelectrode impalement and microinjection of dye. BCNs were imaged using a cooled charge-coupled device camera (Sensicam; PCO Computer Optics, Kelheim, Germany) controlled by a personal computer-based imaging and analysis software (Slide-Book; Intelligent Imaging Innovations, Denver, CO). The fluorescence of furaPE3 was excited alternatively at wavelengths of $340 \mathrm{~nm}\left(F_{340}\right)$ and $380 \mathrm{~nm}$ $\left(F_{380}\right)$ using a rotating filter wheel (Lambda 10-2; Sutter Instruments). Emitted light was collected through a dichroic filter, and optical images (12 bits) were acquired every 1-30 sec depending on the experiment. The timing of the optical images was coordinated with the electrophysiology data via Transistor-Transistor Logic pulses that were triggered by the imaging software and sent to the electrophysiological data acquisition system, in which they were incorporated into the computer-based chart recording. Cells were filled with indicator dye until the fluorescence intensity measured at $340 \mathrm{~nm}$ over $20 \mathrm{msec}$ reached 2500 arbitrary units, which provides a sufficient signal without overloading the cells. Calibration was performed in vitro using $\mathrm{Ca}^{2+}$ and EGTA-Ca ${ }^{2+}$ buffers adjusted for marine ionic composition (in mM: $500 \mathrm{KCl}, 50 \mathrm{MgCl}_{2}, 10$ morpholinopropanesulfonate, $\mathrm{pH} 7.4$ ) and contained between 0 and $30 \mu \mathrm{M}$ free $\mathrm{Ca}^{2+}$ (calculated using the MAXC program) (Bers et al., 1994). Under these conditions, we determined a $K_{\mathrm{d}}$ of $1036 \mathrm{~nm}$, and the concentration of free $\mathrm{Ca}^{2+}$ was calculated using the following equation: $\left[\mathrm{Ca}^{2+}\right]_{\text {free }}=$ $K_{\mathrm{d}} \times \beta \times\left(R-R_{\min }\right) /\left(R_{\max }-R\right)$ (Grynkiewicz et al., 1985), with $R$ the ratio of $F_{340} / F_{380}, R_{\min }=0.182, R_{\max }=2.727$, and $\beta=2.073$.

Radioimmunoassay. Concentrations of ELH in ASW were measured using the radioimmunoassay procedure described by Wayne and Wong (1994). For the 11 assays performed, the limit of detection was $1.5 \pm 0.2$ $\mathrm{ng} / \mathrm{ml}$ (342 pM; 2 SDs from buffer control values of $100 \mu \mathrm{l}$ aliquots). The intra-assay coefficient of variation of quadruplicate samples containing $14 \pm 0.7$ and $34 \pm 3 \mathrm{ng} / \mathrm{ml}$ averaged $18 \%$, and the interassay coefficient of variation of these samples averaged $20 \%$.

Data analysis. The values in the figures and text are shown as the mean \pm SEM. Baseline values for ELH and $V_{\mathrm{m}}$ are defined as the mean +2 SDs of those values before electrical stimulation. Calculation of baseline for $\left[\mathrm{Ca}^{2+}\right]_{\mathrm{i}}$ took into consideration the slope in resting levels, which occurred over the course of 90 min independent of the stimulation of an AD (see Fig. 1). The IGOR data analysis program (WaveMetrics, Lake Oswego, OR) was used to subtract data values of a linear-fitted curve (from beginning to end of recording) from ratiometric values. These "baseline" subtracted values were averaged for all data points before electrical stimulation and $10 \mathrm{~min}$ before the end of the experiment; 2 SDs above this mean value was considered above baseline. The Pearson correlation test was used to compare the duration of the AD, the decline of post-AD $V_{\mathrm{m}}$ and $\mathrm{Ca}^{2+}$ to baseline, and the total amount of ELH secreted over the entire data set. ANOVA followed by Student's $t$ test was used to compare the time for $\left[\mathrm{Ca}^{2+}\right]_{\mathrm{i}}$ to decline to baseline in the cell soma versus neurite and normal ASW versus EGTA. Student's $t$ test was used to compare ELH values between normal ASW- and EGTAtreated preparations. Values were considered significantly different at a value of $p<0.05$.

\section{RESULTS \\ Relationship between action potential firing and $\left[\mathrm{Ca}^{2+}\right]_{i}$}

Figure 1 shows $\mathrm{Ca}^{2+}$ levels under control conditions in which optical images were taken once every $15 \mathrm{sec}$ in the absence of electrical stimulation. There was a consistent slow and progressive increase in resting $\mathrm{Ca}^{2+}$ values after $\sim 40 \mathrm{~min}$. This same increase in the apparent baseline was seen in the majority of our experiments in which afterdischarges were stimulated, even in those studies in which optical images were taken once every 30 sec. We cannot account for this change in baseline. Figure 2 illustrates the relationship between action potential firing and the $\mathrm{Ca}^{2+}$ signal during the AD. This example was from a $\mathrm{BCN}$ preparation that showed a bursting $\mathrm{AD}$, which is quite rare. Each burst of action potentials was closely followed by a transient increase in $\left[\mathrm{Ca}^{2+}\right]_{i}$, as seen in the ratiometric measurement. 


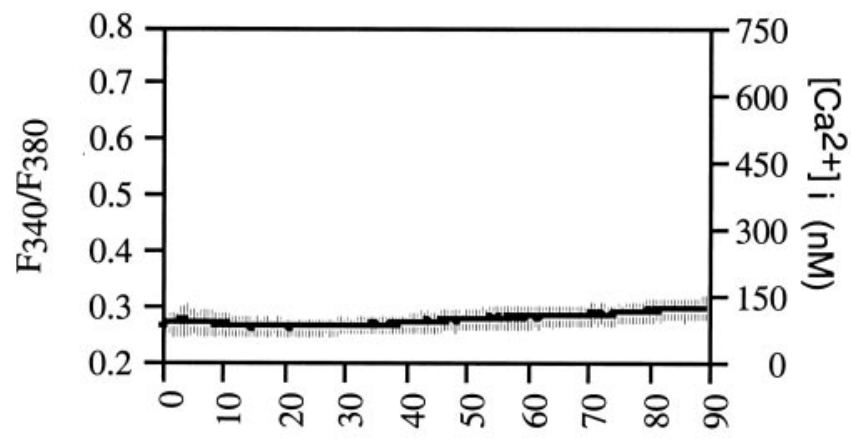

Time (min)

Figure 1. Resting $\mathrm{Ca}^{2+}$ levels in BCN soma in the absence of electrical stimulation. Optical images were taken every $15 \mathrm{sec}$ for $90 \mathrm{~min}$ from six BCNs from six preparations. The $y$-axis at left shows data as the ratio of mean background-subtracted fluorescence intensity at 340 and $380 \mathrm{~nm}$ wavelength of light. The $y$-axis at right shows estimated concentrations of cytosolic calcium $\left(\left[\mathrm{Ca}^{2+}\right]_{\mathrm{i}}\right)$.

\section{0}

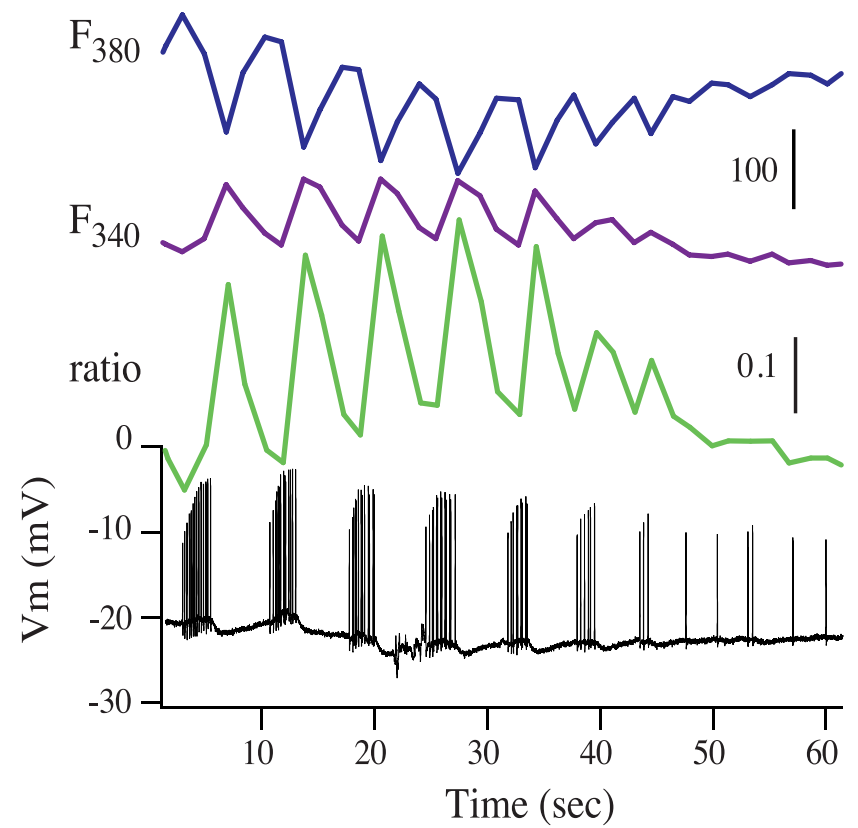

Figure 2. $\mathrm{Ca}^{2+}$ signal during a bursting AD. Top, Images of a single $\mathrm{BCN}$ over time; changes in $\mathrm{Ca}^{2+}$ levels are shown in pseudocolor, with warmer colors indicating a higher $\left[\mathrm{Ca}^{2+}\right]_{\mathrm{i}}$. Middle, $\mathrm{Ca}^{2+}$ signal as the fluorescence intensity at $340 \mathrm{~nm}\left(F_{340}\right)$ and $380 \mathrm{~nm}\left(F_{380}\right)$ wavelength of light and as the ratio of $F_{340}$ to $F_{380}$. Bottom, Changes in $V_{\mathrm{m}}$ and action potential firing during the bursting AD. Scale bars for fluorescence intensity (in arbitrary units) and for the ratio of $F_{340} / F_{380}$ are shown at right. Time axis is the same for all panels.

Importantly, the fluorescence intensity measurement at $340 \mathrm{~nm}$ was the inverse of that at $380 \mathrm{~nm}$ during the AD. To simplify the graphics, only the ratiometric data (and derived estimated calcium concentrations) will be shown in subsequent figures.

Relationship between membrane excitability, $\left[\mathrm{Ca}^{2+}\right]_{\mathrm{i}}$ in the soma, and ELH secretion

Figure 3 shows the pattern of action potential firing $(A), V_{\mathrm{m}}$ (interspike $V_{\mathrm{m}}$ shown during the AD), $\left[\mathrm{Ca}^{2+}\right]_{\mathrm{i}}$, and ELH secre-
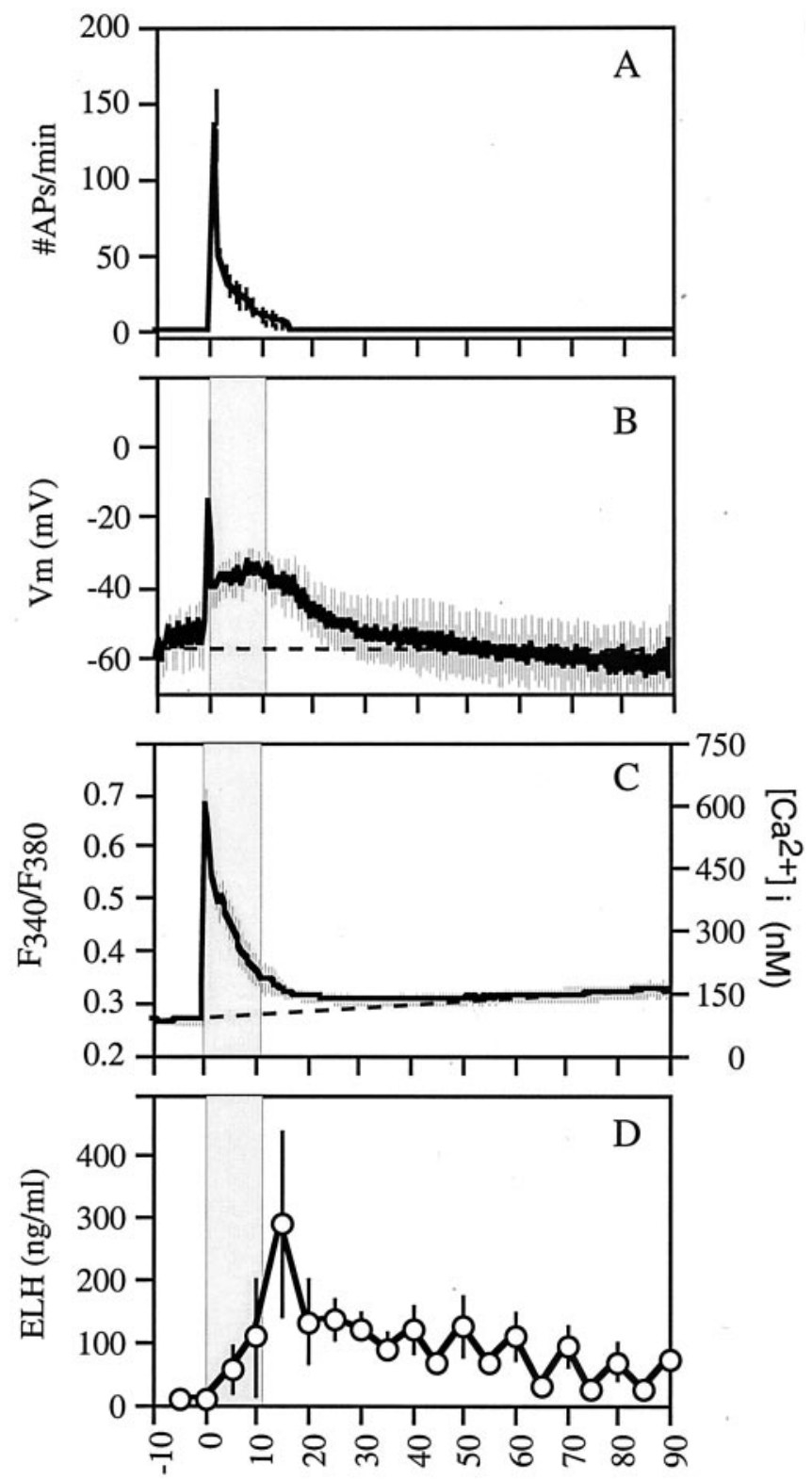

Time (min)

Figure 3. Relationship between the $\mathrm{AD}(A$; shown as the number of action potentials per minute), $V_{\mathrm{m}}(B$; shown in millivolts; interspike interval during the $\mathrm{AD}), \mathrm{Ca}^{2+}$ concentration $(C$; shown as both the ratio $F_{340} / F_{380}$ and estimated $\left.\left[\mathrm{Ca}^{2+}\right]_{\mathrm{i}}\right)$, and ELH secretion $(D$; in nanograms per milliliter) from $\mathrm{BCN}$ soma in preparations maintained in normal ASW. $B-D$, Shaded areas represent the timing and duration of the averaged AD. $B, C$, Dashed lines indicate resting $V_{\mathrm{m}}$ and $\mathrm{Ca}^{2+}$ levels, respectively. $B$ shows $V_{\mathrm{m}}$ recordings from five of the eight preparations in this experiment (the electrode came out of the cell from the remaining 3 preparations early in the experiment).

tion before, during, and after the end of the AD. The average duration of the AD was $11 \pm 2 \mathrm{~min}$. Notably, $V_{\mathrm{m}},\left[\mathrm{Ca}^{2+}\right]_{\mathrm{i}}$, and ELH secretion all persisted after the end of the AD in eight of eight preparations (Table 1). ELH levels were still above baseline in seven of eight preparations by the end of the 90 min experiment. Taking into account the 10 min delay in clearance of ELH from the recording chamber, all eight preparations were still secreting ELH after $V_{\mathrm{m}}$, and $\left[\mathrm{Ca}^{2+}\right]_{\mathrm{i}}$ declined to baseline. 
Table 1. Post-AD membrane potential $\left(V_{m}\right)$, post-AD $\mathrm{Ca}^{2+}$ signal, and ELH secretion from BCNs treated with normal ASW or EGTA

\begin{tabular}{lcll} 
& $\begin{array}{l}\text { Normal } \\
\text { ASW, soma }\end{array}$ & $\begin{array}{l}\text { EGTA, } \\
\text { soma }\end{array}$ & $\begin{array}{l}\text { Normal } \\
\text { ASW, neurite }\end{array}$ \\
\hline $\begin{array}{l}V_{\mathrm{m}} \text {, post-AD decline to } \\
\text { baseline (min) }\end{array}$ & $22.5 \pm 8$ & $27.8 \pm 8$ & - \\
$\begin{array}{l}\mathrm{Ca}^{2+} \text {, post-AD decline to } \\
\text { baseline (min) }\end{array}$ & $42 \pm 7$ & $43 \pm 10$ & $11 \pm 4^{*}$ \\
$\begin{array}{l}\text { Total ELH secreted } \\
(\mathrm{ng} / \mathrm{ml})\end{array}$ & $1290 \pm 388$ & $2182 \pm 667$ & -
\end{tabular}

${ }^{*} p<0.005$ compared with normal ASW, soma.

\section{Effect of preventing $\mathrm{Ca}^{2+}$ influx on membrane excitability, $\left[\mathrm{Ca}^{2+}\right]_{\mathrm{i}}$ in the soma, and ELH secretion}

Initiation and maintenance of the AD requires $\mathrm{Ca}^{2+}$ influx, and, in turn, activation of ELH secretion is dependent on the AD (Wayne and Frumovitz, 1995). To test whether $\mathrm{Ca}^{2+}$ influx plays an important role in post-AD BCN functions, it was necessary to first initiate the $\mathrm{AD}$ and then prevent $\mathrm{Ca}^{2+}$ entry. In the present experiment, treatment with the calcium chelator EGTA was initiated within $30 \mathrm{sec}$ of the onset of the AD. This solution contains $39 \mathrm{~nm}$ free $\mathrm{Ca}^{2+}$ (Wayne and Frumovitz, 1995), which is below resting $\left[\mathrm{Ca}^{2+}\right]_{\mathrm{i}}$. The reduction of extracellular $\left[\mathrm{Ca}^{2+}\right]$ led to a shortened AD, averaging $5 \pm 1 \mathrm{~min}$ (range, $7 \mathrm{sec}$ to $9 \mathrm{~min}$ ), compared with preparations stimulated in normal ASW $(p<$ 0.005) (compare Figs. 3, 4). The variability in the duration of AD of the EGTA-treated group can be accounted for by inconsistencies in the rate at which individual preparations achieved complete perfusions of solution, which is partly a function of variability in vascularization of the abdominal ganglia. Figure 4 and Table 1 show that, compared with preparations stimulated in the presence of normal ASW, treatment with EGTA had no effect on the post-AD decline in $V_{\mathrm{m}}$ or $\left[\mathrm{Ca}^{2+}\right]_{\mathrm{i}}$. Furthermore, as shown previously (Wayne and Frumovitz, 1995; Wayne et al., 1998a), preventing $\mathrm{Ca}^{2+}$ influx did not inhibit ELH secretion (Table 1). ELH had not declined to baseline by the end of the experiment in any of the preparations in this group. Even the preparation that showed a $7 \mathrm{sec}$ AD (just 43 action potentials) secreted high amounts of ELH over a prolonged period of time (total of 683 $\mathrm{ng} / \mathrm{ml}$ for $\geq 90 \mathrm{~min}$ ). This result indicates that the post-AD elevation in $\left[\mathrm{Ca}^{2+}\right]_{\mathrm{i}}$ is not a result of $\mathrm{Ca}^{2+}$ influx from extracellular fluid.

\section{$\mathrm{Ca}^{2+}$ signal in the neurite}

Figure 5 shows the relationship between membrane excitability in BCNs and $\left[\mathrm{Ca}^{2+}\right]_{\mathrm{i}}$ in their respective neurites, in which presumably most of ELH secretion is taking place (Fisher et al., 1988; Roubos et al., 1990). BCN neurites vary tremendously in length, from $<500 \mu \mathrm{m}$ for those that terminate within the BCN cluster to several centimeters for those that traverse the pleurovisceral connective nerve toward the head ganglia (Kaczmarek et al., 1979; Shope et al., 1991). The calcium indicator dye, however, did not diffuse in sufficient quantities to monitor fluorescence past $120 \mu \mathrm{m}$ along the neurites with the optics used in this study. Therefore, all neurite data are shown in a region that is within $100 \mu \mathrm{m}$ of the soma. As in the soma, there was a slow decline in the levels of $\mathrm{Ca}^{2+}$ to baseline in the neurite; however, $\left[\mathrm{Ca}^{2+}\right]_{\mathrm{i}}$ in the neurite reached baseline significantly earlier than that in the soma (Table 1). Figure 6 shows an example of a $\mathrm{BCN}$ in which the $\mathrm{Ca}^{2+}$ signal was monitored in the soma, the proximal neurite,
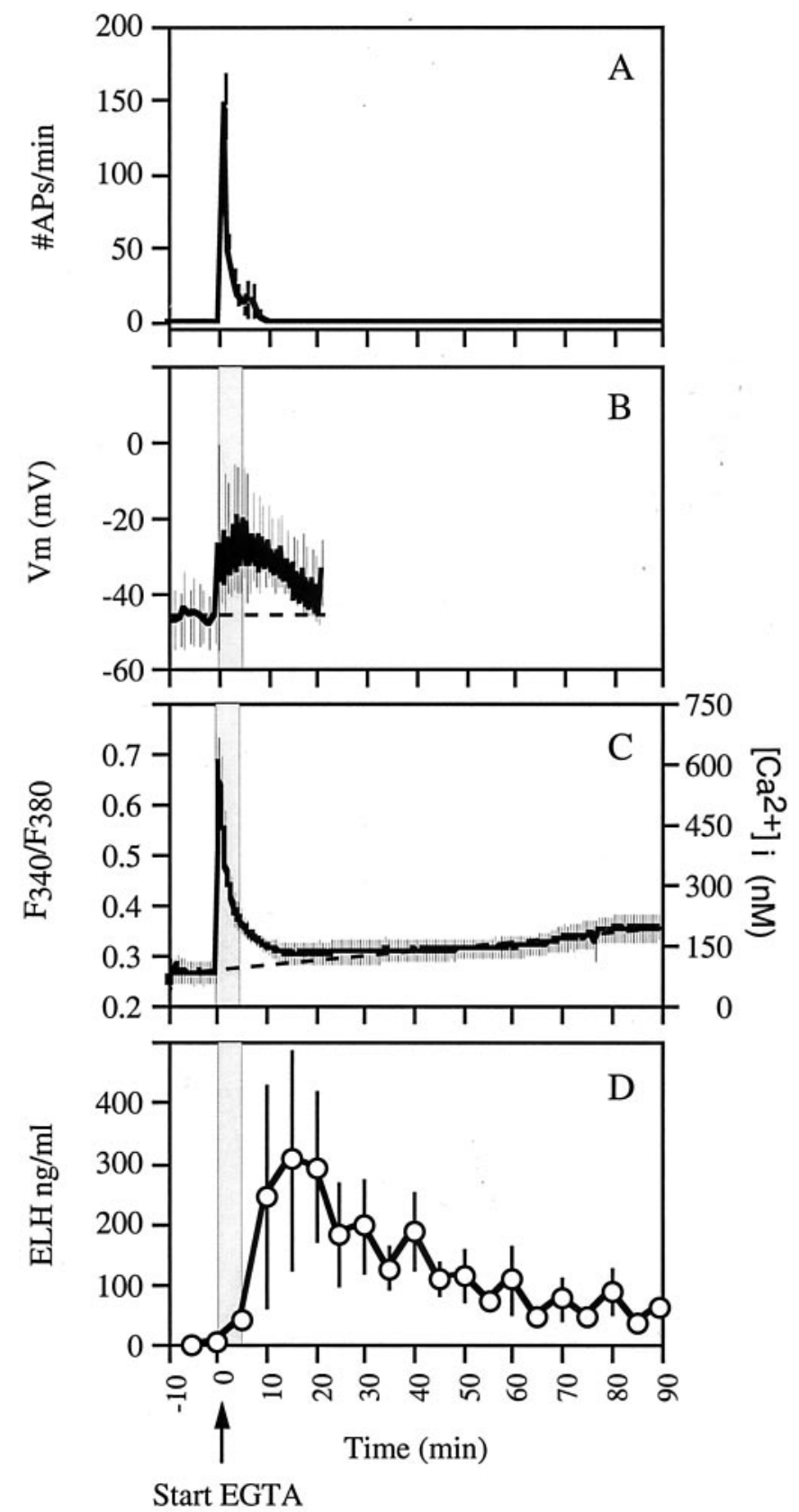

Figure 4. Relationship between the $\mathrm{AD}, V_{\mathrm{m}}$, calcium concentration, and ELH secretion from BCN soma in preparations treated with EGTA within $30 \mathrm{sec}$ after onset of the AD. $B-D$, Shaded areas represent the timing and duration of the averaged AD. $B, C$, Dashed lines indicate resting $V_{\mathrm{m}}$ and $\mathrm{Ca}^{2+}$ levels, respectively. $B, V_{\mathrm{m}}$ recordings from three of the eight preparations in this experiment (the electrode came out of the cell from the remaining 5 preparations early in the experiment).

and what is most likely the neurite terminal. The fluorescence in this BCN ended abruptly in a knob-like structure, with no outof-plane fluorescence in that region, thus suggesting that the knob was the terminal of a short neurite (as described by Kaczmarek et al., 1979). Although there were slight differences in the magnitude of $\mathrm{Ca}^{2+}$ levels in those three areas of the neuron during the AD, in this example, all three regions showed a similar slow post-AD decline in $\mathrm{Ca}^{2+}$ toward baseline. Overall, these findings indicate that the $\mathrm{Ca}^{2+}$ signal remains elevated above baseline after the end of the $\mathrm{AD}$ in all regions of the $\mathrm{BCN}$, at least when we 

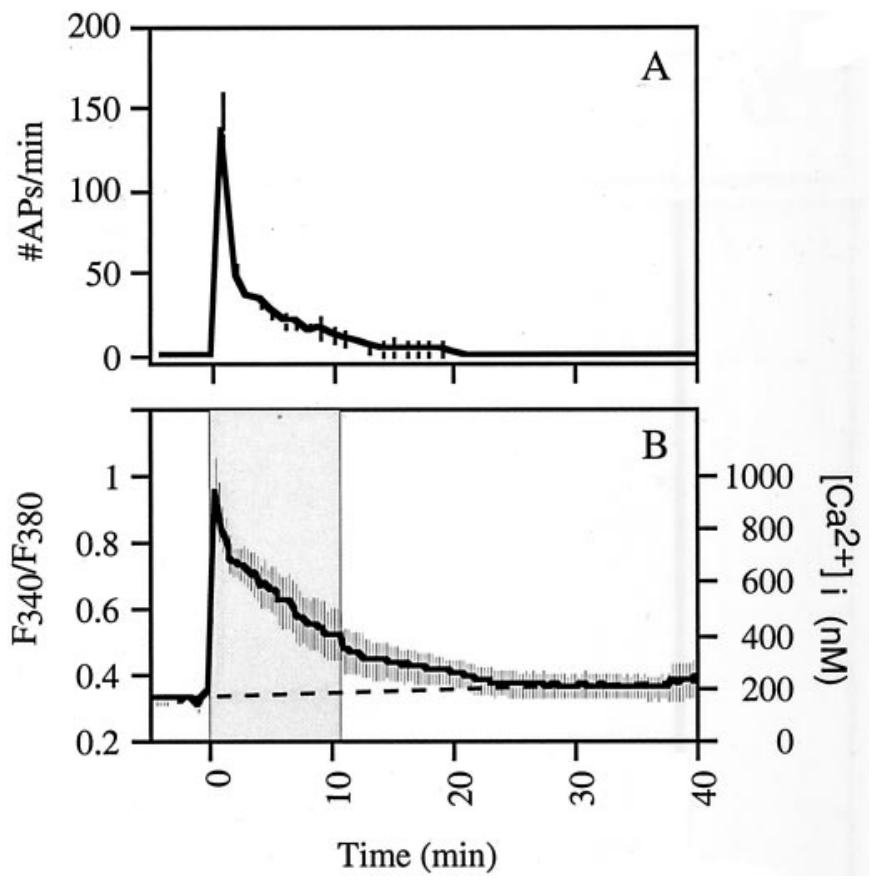

Figure 5. Relationship between the $\mathrm{AD}$ and calcium concentration from BCN neurites maintained in normal ASW (6 neurites from 6 preparations). $B$, Shaded area represents the timing and duration of the averaged AD. Dashed line indicates resting $\mathrm{Ca}^{2+}$ levels.

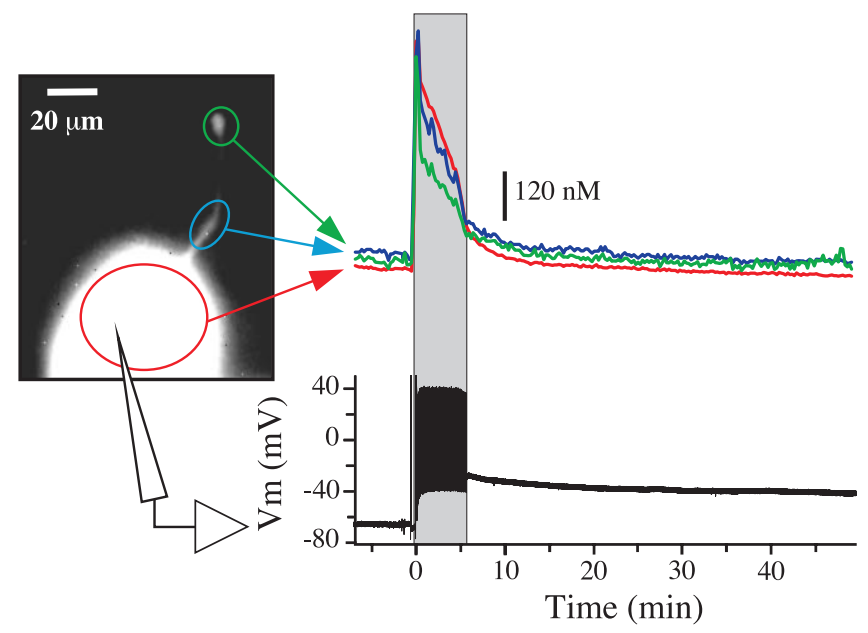

Figure 6. Calcium signal in representative $\mathrm{BCN}$ soma, proximal neurite, and distal neurite. Bottom, $V_{\mathrm{m}}$ and action potential firing. Top, Changes in $\mathrm{Ca}^{2+}$ levels (as the estimated $\left[\mathrm{Ca}^{2+}\right]_{\mathrm{i}}$ ) throughout the experiment from the three different regions of the $\mathrm{BCN}$ shown at left. The thin open triangle represents the sharp microelectrode used to monitor $V_{\mathrm{m}}$; the wide open triangle symbolizes the amplifier.

consider neurites with short projections. Because the bulk of ELH secretion comes from the BCN cluster rather than from neurites in the pleurovisceral connective nerve (Wayne and Wong, 1994), any differences in the calcium signal from distal neurites in this nerve would have little impact on the overall pattern of ELH secretion.

\section{Evaluation of possible correlations between different BCN functions}

There was no significant correlation between the duration of the $\mathrm{AD}$ and the time that $V_{\mathrm{m}}$ declined to baseline $(r=-0.23)$, the time that $\left[\mathrm{Ca}^{2+}\right]_{\mathrm{i}}$ declined to baseline $(r=-0.22)$, or the total amount of ELH secreted $(r=-0.14)$. There was no significant correlation between total amount of ELH secreted and the time that $V_{\mathrm{m}}$ declined to baseline $(r=0.12)$ or the time that $\left[\mathrm{Ca}^{2+}\right]_{\mathrm{i}}$ declined to baseline $(r=0.26)$. These findings suggest that the $\mathrm{AD}$ acts as a triggering mechanism rather than a sustained driving force for downstream cellular events, including prolonged membrane depolarization, $\mathrm{Ca}^{2+}$ release from intracellular stores, and ELH secretion. Furthermore, neither prolonged membrane depolarization nor post-AD elevation in $\left[\mathrm{Ca}^{2+}\right]_{\mathrm{i}}$ can account for the entire post-AD period of ELH secretion.

\section{DISCUSSION}

Influx of $\mathrm{Ca}^{2+}$ from extracellular fluid and elevated $\left[\mathrm{Ca}^{2+}\right]_{i}$ are commonly associated with secretion of transmitter or peptide from neurons (Bennett, 1997; Kits and Mansvelder, 2000). Our previous work brought into question whether this model could be extended to BCNs that secrete peptide hormone over a prolonged period of time. Preventing $\mathrm{Ca}^{2+}$ influx shortly after onset of the AD did not inhibit ELH secretion, although the duration of the AD was significantly abbreviated (Wayne and Frumovitz, 1995; Wayne et al., 1998a) (Fig. 4). Furthermore, release of $\mathrm{Ca}^{2+}$ from intracellular stores in the absence of both $\mathrm{AD}$ and $\mathrm{Ca}^{2+}$ influx stimulated sustained ELH secretion (Wayne et al., 1998a). These findings in BCNs suggested a model in which the AD triggers some cellular event(s) leading to prolonged release of $\mathrm{Ca}^{2+}$ from intracellular stores that might drive prolonged ELH secretion. Our present findings confirm that, once the AD is initiated, $\mathrm{Ca}^{2+}$ influx from extracellular fluid is not necessary to maintain a normal pattern of ELH secretion. The results also show that not only does the AD trigger prolong ELD secretion, but also leads to prolonged membrane depolarization and $\mathrm{Ca}^{2+}$ elevation, all of which persist after the end of the AD. This post-AD elevation in $\left[\mathrm{Ca}^{2+}\right]_{\mathrm{i}}$ was not altered in the presence of extracellular EGTA, indicating that it was not a result of $\mathrm{Ca}^{2+}$ influx from extracellular fluid. Notably, $V_{\mathrm{m}}$ repolarized to resting levels and $\left[\mathrm{Ca}^{2+}\right]_{\mathrm{i}}$ declined to baseline well before ELH secretion. Therefore, the post-AD membrane depolarization and elevation in $\left[\mathrm{Ca}^{2+}\right]_{\mathrm{i}}$ cannot fully account for the prolonged release of ELH; perhaps some additional cellular event is playing an important role in mediating the effect of AD on neurohormone secretion. Importantly, this work was done using an intact nervous preparation in which the integrity of the neuroendocrine network was maintained in vitro. Changes in membrane excitability and hormone secretion from this excised $\mathrm{BCN}$ preparation are comparable with those observed in freely behaving animals, suggesting that the data from the present study are of physiological and behavioral relevance (Wayne, 1994, 1995).

There is precedence in other neurosecretory cells for persistent elevation in $\left[\mathrm{Ca}^{2+}\right]_{\mathrm{i}}$ after the end of some stimulus. Previous work in reproductive neuroendocrine cells in the freshwater pond snail Lymnaea stagnalis that are highly analogous to BCNs showed that $\left[\mathrm{Ca}^{2+}\right]_{\mathrm{i}}$ in the peptidergic caudodorsal cell neurons rose threefold to fourfold during an electrical $\mathrm{AD}$ and, as with BCNs, remained elevated for tens of minutes after the end of the AD (Kits et al., 1997). However, simultaneous measurements of caudodorsal cell hormone secretion and $\mathrm{Ca}^{2+}$ have not been reported; thus, the temporal relationship between the $\mathrm{Ca}^{2+}$ signal and caudodorsal cell hormone has not been determined. The gonadotropin releasing hormone $(\mathrm{GnRH})$ neurons of the mammalian hypothalamus and the gonadotropes of the anterior pituitary provide another example of a reproductive system in which 
$\mathrm{Ca}^{2+}$ release from intracellular stores plays an important role in regulating peptide hormone release. In this mammalian system, GnRH binds to receptors on pituitary gonadotropes, activating $\mathrm{Ca}^{2+}$ oscillations that are accompanied by rhythmic exocytosis. Both the $\mathrm{Ca}^{2+}$ oscillations and rhythmic exocytosis persist after the end of the GnRH stimulus, occur in the absence of $\mathrm{Ca}^{2+}$ influx from extracellular fluid, and can be triggered by an $\mathrm{IP}_{3}$ mediated mechanism that releases $\mathrm{Ca}^{2+}$ from intracellular stores (Tse et al., 1993). Work in embryonic primate GnRH neurons have shown that, as with the gonadotropes, there are oscillations in $\left[\mathrm{Ca}^{2+}\right]_{i}$ and peptide secretion (Terasawa et al., 1999a,b). Although preventing $\mathrm{Ca}^{2+}$ influx eliminated pulsatile $\mathrm{GnRH}$ secretion, there was evidence that $\mathrm{Ca}^{2+}$ release from intracellular stores contributed to some aspect of the pattern of GnRH secretion. That is, pharmacological mobilization of $\mathrm{Ca}^{2+}$ from ryanodine-sensitive and mitochondrial stores stimulated significant amounts of GnRH secretion (Terasawa et al., 1999a).

In the present study, the post-AD elevation in $\left[\mathrm{Ca}^{2+}\right]_{i}$ persisted in the presence of extracellular EGTA. This slow decline of $\left[\mathrm{Ca}^{2+}\right]_{\mathrm{i}}$ could be a result of inefficient buffering or extrusion of $\mathrm{Ca}^{2+}$ after the end of the AD. The kinetics of $\mathrm{Ca}^{2+}$ buffering in other cell types is reported to be on the order of seconds $(\mathrm{Xu}$ et al., 1997; Kits and Mansvelder, 2000) and not tens of minutes; however, this process could be extremely slow in BCNs. Another possible explanation for the post-AD elevation in $\left[\mathrm{Ca}^{2+}\right]_{i}$ is release of $\mathrm{Ca}^{2+}$ from intracellular stores. There is evidence for this in $\mathrm{BCNs}$ from previous studies showing that $\mathrm{IP}_{3}$ stimulates an increase in $\left[\mathrm{Ca}^{2+}\right]_{\mathrm{i}}$ in both soma and neurites (Fink et al., 1988) and that $\mathrm{Ba}^{2+}$ influx through VSCCs can trigger $\mathrm{Ca}^{2+}$ release as measured by a calcium-selective electrode in the cell soma (Fisher et al., 1994). This brings up the possibility that, during the $\mathrm{AD}$, multiple pathways could be activated that contribute to the $\mathrm{Ca}^{2+}$ signal, including $\mathrm{Ca}^{2+}$ influx from extracellular fluid, $\mathrm{Ca}^{2+}$-induced $\mathrm{Ca}^{2+}$ release from intracellular stores, and synaptic stimulation of an $\mathrm{IP}_{3}$-sensitive store. The $\mathrm{BCN}$ intracellular store that might be contributing to the $\mathrm{AD}$-induced $\mathrm{Ca}^{2+}$ signal has not yet been identified.

There is a temporal dissociation between peak $\left[\mathrm{Ca}^{2+}\right]_{\mathrm{i}}$ and peak ELH secretion in the present study. Quite noticeably, the bulk of the $\mathrm{Ca}^{2+}$ signal occurred during the $\mathrm{AD}$, whereas the bulk of ELH secretion occurred after the end of the AD. This delay in ELH secretion relative to the pattern of action-potential firing and $\left[\mathrm{Ca}^{2+}\right]_{\mathrm{i}}$ cannot be accounted for by the delay in clearance of solution through the recording chamber, because there is $95 \%$ clearance within two samples or $10 \mathrm{~min}$. Importantly, in freely behaving Aplysia, concentrations of ELH in hemolymph are elevated for $>40$ min after the end of the AD, although this hormone has a half-life of $\sim 3$ min (Wayne, 1994). Also, in the present study, $\left[\mathrm{Ca}^{2+}\right]_{\mathrm{i}}$ reached baseline well before ELH secretion declined to baseline, suggesting that maintenance of prolonged ELH secretion is not dependent on either $\mathrm{Ca}^{2+}$ influx from extracellular fluid or release from intracellular stores. If $\mathrm{Ca}^{2+}$ is not driving prolonged ELH secretion, then what alternative mechanisms could be stimulating peptide release? One potential component is membrane depolarization leading to some long-lasting $\mathrm{Ca}^{2+}$-independent mechanism. Certainly, the AD led to a robust and sustained depolarization of $V_{\mathrm{m}}$ that was very slow to repolarize to resting levels. However, like the $\mathrm{Ca}^{2+}$ signal, $V_{\mathrm{m}}$ reached baseline well before ELH secretion. Nevertheless, prolonged membrane depolarization could be stimulating an even longer activation of some other signaling pathway that plays an important role in ELH secretion.
Our previous work showed that both cAMP-dependent protein kinase and calcium/phospholipid-dependent protein kinase (PKC) play important roles in mediating the effects of AD on ELH secretion (Wayne et al., 1998b). Furthermore, AD stimulated rapid and prolonged activation of both the calciumactivated and calcium-independent forms of PKC from BCNs, with a time course that was similar to that of ELH secretion (Wayne et al., 1999). Given the findings in the present study, it is especially intriguing that the calcium-independent PKC showed persistent activation in response to AD. Work in rat anterior pituitary gonadotropes has also implied a role for PKC in stimulating peptide hormone secretion in the absence of elevated $\left[\mathrm{Ca}^{2+}\right]_{\mathrm{i}}$ (Billiard et al., 1997). Additional support for $\mathrm{Ca}^{2+}$ independent exocytosis in neurons comes from studies in which ethanol-induced secretion in avian ciliary ganglion neurons (Brosius et al., 1992), nitric-oxide induced exocytosis in hippocampal synaptosomes (Meffert et al., 1994), and $\mathrm{Na}^{+}$-induced secretion in neurohypophysial nerve endings (Stuenkel and Nordmann, 1993 ) occurred in the absence of increases in $\left[\mathrm{Ca}^{2+}\right]_{\mathrm{i}}$. Although the biochemical-molecular mechanism(s) by which exocytosis can be activated in the absence of a rise in $\left[\mathrm{Ca}^{2+}\right]_{i}$ has not been revealed, the possibility of kinase- or neuromodulator-activated allosteric modification of $\mathrm{Ca}^{2+}$-sensitive exocytotic proteins has been postulated as a potential mechanism (Meffert et al., 1994; Billiard et al., 1997). Our findings in BCNs lend support to the importance of an alternative mechanism controlling neurosecretion in which neither $\mathrm{Ca}^{2+}$ influx nor elevated $\left[\mathrm{Ca}^{2+}\right]_{\mathrm{i}}$ is required.

\section{REFERENCES}

Bennett MK (1997) $\mathrm{Ca}^{2+}$ and the regulation of neurotransmitter secretion. Curr Opin Neurobiol 7:316-322.

Bernheim SM, Mayeri E (1995) Complex behavior induced by egglaying hormone in Aplysia. J Comp Physiol [A] 176:131-136.

Bers DM, Patton CW, Nuccitelli R (1994) A practical guide to the preparation of $\mathrm{Ca}^{2+}$ buffers. Methods Cell Biol 40:3-29.

Billiard J, Koh D-S, Babcock DF, Hille B (1997) Protein kinase C as a signal for exocytosis. Proc Natl Acad Sci USA 94:12192-12197.

Brosius DC, Hackett JT, Tuttle JB (1992) $\mathrm{Ca}^{2+}$-independent and $\mathrm{Ca}^{2+}$ dependent stimulation of quantal neurosecretion in avian ciliary ganglion neurons. J Neurophysiol 68:1229-1234.

Chiu AY, Hunkapiller MW, Heller E, Stuart DK, Hood LE, Strumwasser F (1979) Purification and primary structure of the neuropeptide egglaying hormone of Aplysia californica. Proc Natl Acad Sci USA 76:6656-6660

Dunlap K, Holz GG, Lindgren CA, Moore JW (1989) Calcium channels that regulate neurosecretion. Soc Gen Physiol Series 44:239-250.

Fieber LA (1995) Characterization and modulation of $\mathrm{Na}^{+}$and $\mathrm{Ca}^{2+}$ currents underlying the action potential in bag cells of two species of Aplysia. J Exp Biol 198:2337-2347.

Fink LA, Connor JA, Kaczmarek LK (1988) Inositol trisphosphate releases intracellularly stored calcium and modulates ion channels in molluscan neurons. J Neurosci 8:2544-2555.

Fisher JM, Sossin W, Newcomb R, Scheller RH (1988) Multiple neuropeptides derived from a common precursor are differentially packaged and transported. Cell 54:813-822.

Fisher TE, Levy S, Kaczmarek LK (1994) Transient changes in intracellular calcium associated with a prolonged increase in excitability in neurons of Aplysia californica. J Neurophysiol 71:1254-1257.

Grynkiewicz G, Poenie M, Tsien RY (1985) A new generation of $\mathrm{Ca}^{2+}$ indicators with greatly improved fluorescence properties. J Biol Chem 260:3440-3450.

Heller E, Kaczmarek LK, Hunkapiller MW, Hood LE, Strumwasser F (1980) Purification and primary structure of two neuroactive peptides that cause bag cell afterdischarge and egg-laying in Aplysia. Proc Natl Acad Sci USA 77:2328-2332.

Kaczmarek LK, Finbow M, Revel JP, Strumwasser F (1979) The morphology and coupling of Aplysia bag cells within the abdominal ganglion and in cell culture. J Neurobiol 10:535-550.

Katz B, Miledi R (1967) The timing of calcium action during neuromuscular transmission. J Physiol (Lond) 189:535-544.

Kits KS, Mansvelder HD (2000) Regulation of exocytosis in neuroendocrine cells: spatial organization of channels and vesicles, stimulus- 
secretion coupling, calcium buffers and modulation. Brain Res Rev 33:78-94.

Kits KS, Dreijer AMC, Lodder JC, Borgdorff A, Wadman WJ (1997) High intracellular calcium levels during and after electrical afterdischarges in molluscan peptidergic neurons. Neuroscience 79:275-284.

Kupfermann I, Kandel ER (1970) Electrophysiological properties and functional interconnections of two symmetrical neurosecretory clusters (bag cells) in abdominal ganglion of Aplysia. J Neurophysiol 33:865-876.

Mason WT, Hatton GI, Kato M, Bicknell RJ (1992) Signal transduction in the neurohypophyseal compartments. In: Progress in brain research, Vol 92 (Joose J, Buijs RM, Tilders FJH, eds), pp 267-276. New York: Elsevier Science.

Mayeri E, Rothman BS, Brownell PH, Branton WD, Padgett L (1985) Nonsynaptic characteristics of neurotransmission mediated by egglaying hormone in the abdominal ganglion of Aplysia. J Neurosci 5:2060-2077.

Meffert MK, Premack BA, Schulman H (1994) Nitric oxide stimulates $\mathrm{Ca}^{2+}$-independent synaptic vesicle release. Neuron 12:1235-1244.

Newcomb RW, Scheller RH (1990) Regulated release of multiple peptides from the bag cell neurons of Aplysia californica. Brain Res 521:229-237

Rothman BS, Weir G, Dudek FE (1983) Egg-laying hormone: direct action on the ovotestis of Aplysia. Gen Comp Endocrinol 52:134-141.

Roubos EW, van de Ven AMH, ter Maat A (1990) Quantitative ultrastructural tannic acid study of the relationship between electrical activity and peptide secretion by the bag cell neurons of Aplysia californica. Neurosci Lett 111:1-6.

Schwartz EA (1987) Depolarization without calcium can release $\gamma$-aminobutyric acid from a retinal neuron. Science 238:350-355.

Shope SB, McPherson D, Rock MK, Blankenship JE (1991) Functional and morphological evidence for the existence of neurites from abdominal ganglion bag cell neurons in the head-ring ganglia of Aplysia. J Comp Physiol [A] 168:539-552.

Stuenkel EL, Nordmann JJ (1993) Sodium-evoked, calcium-independent vasopressin release from rat isolated neurohypophysial nerve endings. J Physiol (Lond) 468:357-378.

Terasawa E, Keen KL, Mogi K, Claude P (1999a) Pulsatile release of luteinizing hormone-releasing hormone (LHRH) in cultured LHRH neurons derived from the embryonic olfactory placode of the rhesus monkey. Endocrinology 140:1432-1441.
Terasawa E, Schanhofer WK, Keen KL, Luchansky L (1999b) Intracellular $\mathrm{Ca}^{2+}$ oscillations in luteinizing hormone-releasing hormone neurons derived from the embryonic olfactory placode of the rhesus monkey. J Neurosci 19:5898-5909.

Tse A, Tse FW, Almers W, Hille B (1993) Rhythmic exocytosis stimulated by $\mathrm{GnRH}$-induced calcium oscillations in rat gonadotropes. Science 260:82-84.

Tse FW, Tse A, Hille B, Horstmann H, Almers W (1997) Local Ca ${ }^{2+}$ release from internal stores controls exocytosis in pituitary gonadotrophs. Neuron 18:121-132.

Wayne N (1994) Role of cyclic AMP-dependent protein kinase (PKA) in regulating egg-laying hormone $(\mathrm{ELH})$ secretion from Aplysia bag cells. Netherlands J Zool 44:588-598.

Wayne NL (1995) The neuroendocrine bag cells of Aplysia: a model system for neural control of hormone secretion. J Endocrinol 147:1-4.

Wayne NL, Frumovitz M (1995) Calcium influx following onset of electrical afterdischarge is not required for hormone secretion from neuroendocrine cells of Aplysia. Endocrinology 136:369-372.

Wayne NL, Michel S (2001) Membrane excitability, calcium signaling, and neuropeptide secretion from neuroendocrine cells in the intact nervous system. Soc Neurosci Abstr 27:126.1.

Wayne NL, Wong H (1994) Persistence of hormone secretion from neuroendocrine cells of Aplysia following termination of electrical afterdischarge. Endocrinology 134:1046-1054.

Wayne NL, Kim J, Lee E (1998a) Prolonged hormone secretion from neuroendocrine cells of Aplysia is independent of extracellular calcium. J Neuroendocrinol 10:529-537.

Wayne NL, Kim YJ, Yong-Montenegro RJ (1998b) Seasonal fluctuations in the secretory response of neuroendocrine cells of Aplysia californica to inhibitors of protein kinase $\mathrm{A}$ and protein kinase $\mathrm{C}$. Gen Comp Endocrinol 109:356-365.

Wayne NL, Lee W, Kim YJ (1999) Persistent activation of calciumactivated and calcium-independent protein kinase $\mathrm{C}$ in response to electrical afterdischarge from peptidergic neurons of Aplysia. Brain Res 834:211-213.

Xu T, Naraghi M, Kang H, Neher E (1997) Kinetic studies of Ca ${ }^{2+}$ binding and $\mathrm{Ca}^{2+}$ clearance in the cytosol of adrenal chromaffin cells. Biophys J 73:532-545. 